\title{
Wally Olins (1930-2014), corporate identity ascendancy and corporate brand hegemony. Celebrating the life of Wally Olins: Leading corporate identity exponent and prominent brand proponent
}

\author{
Professor John M T Balmer \\ Professor of Corporate Marketing \\ Brunel University Business School \\ Brunel University \\ London
}

The United Kingdom

This is an earlier version of an article published by Palgrave in

The Journal of Brand Management

Kindly refer to the publication for citation purposes:

Balmer JMT (2014). “Wally Olins (1930-2014), corporate identity ascendancy and corporate brand hegemony. Celebrating the life of Wally Olins: Leading corporate identity exponent and prominent brand proponent", Journal of Brand Management Vol. 21, pp. 459-468 


\begin{abstract}
This article outlines the nature, significance and legacy of Wally Olins (1930-2014) vis-a-vis corporate identity and brand management. Celebrated for his corporate identity/corporate brand consultancy work he is also known for his considerable published output relating to corporate identity and branding. In the writer's estimation, Olins helped to inspire a generation of marketing scholars who, in turn, established corporate identity a distinct area of marketing thought. The author notes the significance of his binary definitions of corporate identity. Olins states that corporate identity is essentially design focused. He also states that it relates to an institution's core traits and activities. As such, his reflections explain why, today, there are different approaches (both academic and practitioner) to the area. His explication of the corporate personality is also of note. It is argued that Olins was part of the English corporate-level marketing revolution where, along with academics and practitioners, the later including David Bernstein and Stephen King, he accorded importance not only to products and services in marketing contexts but, significantly, to corporations and other organisations too. For much of his career (1965-2000) he was a champion for corporate identity and the author herein offers two explanations why Olins distanced himself from the corporate identity construct post 2000 and focused on brands, and corporate brands.
\end{abstract}

\title{
Keywords:
}

brands; corporate brand; corporate marketing; corporate identity; corporate personality 


\section{"Let us now praise famous men, and our fathers that begat us". (Ecclesiasticus 44:1)}

\section{INTRODUCTION}

Many readers of JBM will share my profound sense of loss at the news of the death of the illustrious British corporate identity and brand consultant Wallace (Wally) Olins CBE who died on 14 April 2014, aged 83.

Olins co-founded the Wolff Olins corporate identity consultancy along with the corporate branding agency Saffron. He was a towering figure within the broad corporate marketing domain. Olins was a prolific writer on both corporate identity and branding: his books were translated in 18 different languages.

Few of us can remember a world before Olins. Moreover, because of his age and because he remained, until the very end, active in his consultancy work and publishing (Olins, 2014) his passing came as a shock: Wally Olins seemed invincible. As with so many others, it was a very great privilege to have known him.

Erroneously labelled a graphic designer by some, he was a consummate consultant. Moreover, Olins was a consultant of many parts: strategist, connoisseur of corporate change programmes, corporate psychoanalyst and -when the situated demanded company confidant, confessor and disciplinarian.

For much of his professional life, from the 1960 s onwards, Olins was a cerebral, skilful and successful recruiting sergeant for corporate identity consultancy and scholarship. For the greater part of his career, he was indelibly linked to the corporate identity domain. He unquestionably, and deservedly, was the Doyen of corporate identity consultancy. A scrutiny of his published output is testimony of the energy he invested in making the corporate identity concept better known.

Post-2000, and behind the curve, he followed others in the sector in effecting a volte face by beating the drum for brands and, more specifically, corporate brands and turned his back on corporate identity. Having embraced the brand perspective with vengeance his branding drum roll became distinctively faster and louder. Regrettably, this drowned-out many of the great twentieth-century corporate identity themes that Olins and others had played-out. Wally Olins, in effect, underwent something of an identity change himself: having been protagonist for corporate identity he very much became the face of brand consultancy. Arguably, this personal change of focus was his most successful of all his managed identity change programmes.

Yet, it is an undeniable truth that his writing on corporate identity spurred scholars not only to establish corporate identity as an area of academic research, but also led leading business schools to offer courses in strategic corporate identity management: Bradford University School of Management and the Department of Marketing at Strathclyde Business School are British cases in point. Erstwhile, corporate identity practitioners may be surprised to learn that today corporate identity is one of the most significant strands of scholarship within the 
broad academic field relating to business identity (Melewar et al, 2000, 2001; Balmer, 2002, 2008; Cornelisen et al, 2007; He and Balmer, 2007; Pérez and Rodriguez del Bosque, 2014).

In my assessment of his opus, (and this is where I differ from the evaluation of Olins's contribution, as detailed in the obituaries published in the quality British press) his books and publications on corporate identity represent the most defining and influential of his oeuvre. They are of seminal importance (Olins, 1978, 1979, 1986, 1989) and unquestionably have exerted a profound influence on a generation of scholars, managers and consultants. Even today, they are still cited in the academic literature.

Nation branding was an enduring passion of his as his JBM article attests (Olins, 2002).

Of course, many practitioners and scholars will have been influenced by his more recent publications on brands and corporate brands per se (Olins, 2004, 2008, 2014).

Yet, identities - both human and corporate - inevitably die. A Benedictine Abbot once mused that the point of an education at a Benedictine school was to prepare students for death. Odd? Not so. A man of wisdom, the good Abbot realised that, by doing so, his students would seize life's opportunities and follow a full and highly meaningful existence. In this regard, Olins, unquestionably, lived a very full and a highly meaningful life.

In this very personal tribute to Wally Olins CBE, I wish not only to say something of the man and his achievements, but also give an individual assessment of his impact and muse on the nature of his legacy.

\section{WALLY OLINS THE MAN}

A quintessential English figure, his family background was, in fact, just a little exotic: Wally Olins roots were Russian and Jewish. In character he can, I think, be best described as having an idiosyncratic and inimitable persona. For instance, his strident views and directness were either loved or loathed by senior managers. He famously used to tell senior managers that they must share the power of his convictions.

I distinctly remember one senior manager of a prominent British bank saying how much his board member colleagues relished his intellect and appreciated his directness: it were these attributes which led that financial institution to retain Wolff Olins as their corporate identity change consultant. In many board rooms, when it came to corporate identity programmes, Wally, one suspects, was very much primus inter pares (the first among equals). He knew it and the senior managers knew it. He liked to lead and he fully expected others to follow.

His English persona, apparently, did not always go down well overseas. One prominent New York-based consultant confided that it was his very Englishness that worked against him in the United States. His commercial forays into North America were, seemingly, rather slight. However, his reflections on corporate identity were noticed at Harvard Business School (HBS). At HBS it was his very Englishness that was an asset. My long-time colleague, Professor Stephen Greyser, invited Olins to his MBA elective focusing on corporate communications and corporate identity. Another of my HBS collaborators - Professor Renato Tagiuri - was instrumental in getting his book (Olins, 1989) Corporate Identity: Making Business Strategy Visible Through Design published by HBS Press (the British edition was published by Thames and Hudson). 
His personality was also mirrored by his distinctive and peerless sartorial style. There was also a little of the thespian about him too. His visual identity scheme was his distinctive attire, his look and his commanding presence. His signature wardrobe and accessories drew on an enduring and endearing quadripartite repertoire: a lightly coloured jacket or two-piece suit, a snazzy bow tie and strikingly coloured socks. Then there were his spectacles. In his later years, he sported a pair of seemingly inimitable and retro-looking round black glasses. The latter was reminiscent of images of pre-World War Two continuity announcers of the BBC.

His presentations also had a theatrical quality. There was always a dénouement and, more often than not, a coup de théâtre too.

Cleverly, although he appeared to be from an earlier, somewhat grander, corporate marketing epoch, he countered this impression by his contemporary and often radical views on corporate identity, branding and nation branding. With a slight twinkle in the eye, he also opined on many things relating to the corporate world; the quality of work of competitor consultancies and the contribution (or lack of it) of the academy to corporate identity and corporate brand management etc.

Having read history (as an undergraduate) at Saint Peter's College, Oxford, there was never any doubt that Olins was bright, talented, hardworking, reflective, charming and precocious. Occasionally he could be irascible.

India, history and fast cars were his enduring passions and these interests often infused his writing.

Poignantly, a month after his death (16 May) India elected a new Prime Minister Narendra Modi. Recently, Wally Olins had spoken to Modi about burnishing 'Brand India' and, apparently, this has meaningfully informed Prime Minister Modi's thinking on India's role in the wider world.

\section{PROFESSIONAL LIFE}

Olins's roots were in advertising. He worked for the London-based advertising agency S.H. Benson before moving to Bombay in post-independence India, where he lead up Ogilvy \& Mather. Today, we would call him A Suit.

However, he became disillusioned with the work and the world of advertising but became fascinated by the new realm of corporate identity consultancy.

In 1965, shortly after his return to London, he co-founded, with Michael Wolff, the celebrated London-based corporate identity consultancy: Wolff Olins. He sold his consultancy in 2001 to Omnicom, a US-based advertising and communications corporation, and in 2001 he founded Saffron corporate brand consultants with a former Wolff Olins colleague Jacob Benbunan. Most had assumed that Olins was going to retire. 


\section{ACHIEVEMENTS}

His accomplishments were wide-ranging and were considerable. He led many successful corporate identity/brand change programmes for a wide variety of organisations. A good many of these are cited in his publications. Among the most celebrated change programmes include those for: Aston University (UK), British Oxygen, British Telecom, Cunard, Diageo, Orange, Midland Bank, Prudential, Renault, Repsol, $3 i$ and Volkswagon.

The above being noted, the great corporate identity change programmes of the last century were not, in my estimation, by Wally Olins. Consider the repositioning of the British Monarchy during the First World War; Franks Pick's pioneering corporate identity work for London Transport (Balmer, 2012); the corporate visual identity for KLM Royal Dutch Airlines by the London-based German graphic designer F.H.K. Henrion; the sheer comprehensiveness of the Hong Kong-based airliner Cathay Pacific's corporate identity change (Balmer and Greyser, 2002); and the successive strategic corporate identity and corporate brand initiatives at British Airways (Balmer et al, 2009).

Wally Olins was celebrated for his work on 'Nation Branding' and undertook nation branding initiatives for Poland and Portugal, among other countries.

However, some corporate identity change programmes were unsuccessful. This includes the ill-fated 'Cool Britannia' initiative during the premiership of British Prime Minister Tony Blair. This project took a jaundiced view of Great Britain's identity which many found to be unsophisticated and somewhat naïve. Another was London's Metropolitan Police corporate identity initiative. It was meant to be a groundbreaking cultural change programme and was trumpeted as such (Olins, 1991). It failed. The new visual identity was also controversial: a 'modernistic', and somewhat flaccid, interpretation of the organisation's coat of arms.

\section{Awards}

Wally Olins was the recipient of a number of awards. The most illustrious of these was conferred in 1999, when her Majesty Queen Elizabeth II appointed him a Commander of the Most Excellent Order of the British Empire (CBE) for his corporate identity/design work. Within this chivalric order, a CBE is one notch down from a KBE: a knighthood.

\section{Published output}

His oeuvre - especially that on corporate identity - is without compare among his practitioner contemporaries; publications that were, and still are, thoughtful and inspirational (Olins, 1978, 1979, 1984, 1986, 1989, 1991, 1999, 2000; Olins and Morgan, 1996; Olins and Selame, 1999). Arguably, the most significant of these is his book: The Corporate Personality: An Inquiry Into the Nature of Corporate Identity (Olins, 1978).

\section{ACADEMIC IMPACT: WALLY OLINS BINARY DEFINITION OF CORPORATE IDENTITY AND HIS INSIGHTS ON THE CORPORATE PERSONALITY}

In explaining the nature of corporate identity, Wally Olins offered two very different explanations. The first of Olins's binary viewpoints saw corporate identity in narrow graphic design terms. This of course was in line with the perspectives of many other corporate 
identity practitioners. The second perspective is more holistic and defined corporate identity in terms of an organisation's attributes. Consider the following statements:

1. Graphic Design Perspective Most people think that corporate identity is about symbols, logotypes, colours, typography, even about buildings, products, furniture, about visual appearance, design. And it is. (Olins, 1989, p. 78)

2. Holistic Perspective Corporate Identity is concerned with four major areas of activity: Products/Services-what you make or sell. Environments-where you make or sell it-the place or physical context. Information-how you describe or publicise what you do. Behaviour-how people within the organisation behave to each other and to outsiders. (Olins, 1989, p. 29)

Of particular note is Olins's second iteration of corporate identity, as this advanced the view that corporate identity was something more deeper than graphic design and this perspective (along with Olins's arguments that corporate identity is profoundly linked to strategy, culture and organisational change) has exerted a profound influence on my own work. As a consequence this resulted in a radically different perspective on the corporate identity domain.

\section{Corporate personality}

His thesis on the corporate personality (Olins, 1978) was also influential and, initially, shaped my own thinking on the area. Intriguingly, after 1978 he rarely referred to the corporate personality. This is what Olins said: Corporate personality, on the other hand, embraces the subject at its most profound level. It is the soul, the persona, the spirit, the culture of the organisation manifested in some way. A corporate personality is not necessarily something tangible that you can see, feel of touch-although it may be. The tangible manifestation of a corporate personality is a corporate identity. It is the identity that projects and reflects the reality of the corporate personality. (Olins, 1978, p. 212)

Developing his corporate personality thesis further he argued that organisations in their early years mirrors the personalities of their founders but once they leave - in the absence of a powerful personality - a corporate personality needs to be managed. The first stage was heroic and the second stage technocratic. This is what Olins annunciated: In the first or heroic period of a company's development the personality of the founder gives it its identity. In the second or technocratic phase the carefully cultivated and developed corporate identity is the major element that provides the link. It becomes the substitute for the personality of the entrepreneur. (Olins, 1978, p. 78)

To me, the above represents one of his most significant reflections on the territory.

\section{WHY OLINS EMBRACED THE CORPORATE BRAND NOTION AND REJECTED CORPORATE IDENTITY?}

For the past 15 years (2000-2014) Olins became an energetic proponent of the strategic importance of corporate brands and of corporate brand consultancy. This raises the 
intriguing question why Wally Olins who, as the premier corporate identity consultant of his age, undertook a volte face by disregarding corporate identity and embraced the corporate brand notion from 2000 s onwards.

In my assessment, there were two reasons for this: intellectual and economic. I believe Olins followed the intellectual debate that surfaced on corporate brands (King, 1991; Balmer, 1995, 1998,2001 ) and became, increasingly troubled by the economic impacts of the widespread trend of relabelling corporate identity consultancy as corporate brand consultancy.

\section{The intellectual imperative}

During the early 1990s, two writers argued that a profound shift was taking place in the branding domain and this was going to lead to the company brand (King, 1991) and, moreover, the corporate brand (Balmer, 1995) coming to the fore.

Back in 1991, Stephen King, the celebrated English advertising luminary (and one of the most cerebral consultants of his age) contended that service-orientated company brands (not corporate brands per se) would come to the fore and detailed how they should be managed.

For King (1991) corporate identity, because it had been devalued by its connotation with graphic design, argued that the company brand was a better label. However, King (somewhat confusingly) regarded the company brand and corporate identity as analogous terms. He remarked: The term 'corporate identity' is used my many to mean roughly what I mean by 'company brand'; but since it's even more widely used to mean the company logo, it seems to me to be a dangerous (as well as a cumbersome) phrase (King, 1991).

In 1995, the English marketing academic Balmer (1995) formally introduced the corporate brand notion. His article, seemingly, was the first of its kind to have the corporate brand in its title. However, unlike King (1991) Balmer argued that the corporate brand was not the same as corporate identity. For him, it was a distinct identity type although both were interrelated. For Balmer, corporate brands have their roots in corporate identities.

Moreover, both the corporate identity and the corporate brand were key building blocks of a new marketing gestalt that had an overtly organisational and stakeholder foci Balmer (1998), called this new area corporate marketing.

To repeat, Balmer did not view corporate brands and corporate identities as identical terms. Rather, he saw corporate brands as a highly meaningful and additional identity type and one that was based on a corporate covenant with stakeholders. For Balmer, since corporate brands had their origins in corporate identity, the emergence of the corporate brand perspective actually underscored the importance of corporate identity.

The work of King and Balmer were very much part of the intellectual debate that was increasingly taking place in England. Olins was, I know, aware of the above debate and must have mused on these developments. For instance, Olins regularly attended ICIG symposia (see Figure 1) and was fully cognizant of leading-edge scholarship on corporate identity, corporate brands and corporate marketing from 1994 onwards. 


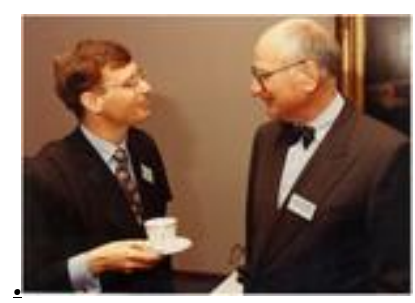

Wally Olins (right) with John Balmer in 1994 at the first international corporate identity group (ICIG) symposium held at the Department of Marketing, Strathclyde University, Scotland. Wally Olins was a regular keynote speaker at ICIG symposia and was, for instance, present at the formal launch of the ICIG at the House of Lords, Palace of Westminster, London in 1995.

\section{The economic imperative}

The economic context for Olins making the strategic change is, I believe, straightforward enough.

Progressively, graphic design driven corporate identity consultancy activities seemed passé and had its detractors (Aldersey-Williams, 2000). The corporate brand notion, in contrast had the benefit of being new; seemed strategic in orientation; and had fewer graphic design associations.

One suspects - because of Olins attachment to corporate identity - his consultancy was losing clients to competitor corporate brand consultancies (mostly erstwhile corporate identity agencies), and this was having an impact on the bottom line.

\section{Olins the pragmatist}

The economic imperative and the diverse intellectual debate relating to corporate identity, corporate brands and company brands (as previously discussed) no doubt unsettled Olins. Reluctantly, he embraced the corporate brand notion and the whole world of brands and, regregattably, eschewed the corporate identity notion which he helped to promulgate.

\section{Olins the uneasy pragmatist}

I once asked him why, in light of his powerful advocacy of corporate identity he embraced the corporate brand notion and crucially turned his back on corporate identity? He admitted that he found this to be painful and explained that he tried to hold out against the change. The forces of change that militated against corporate identity and priviledged corporate brand consultancy were too strong he mused.

Although this made excellent commercial sense there was some sadness among marketing scholars that Wally Olins's reflections and insights on corporate identity (especially in his non-graphic design explications of the construct) had ended.

\section{A PERSONAL TRIBUTE}

Without doubt, my initial research, writing and teaching on corporate identity has been inspired, shaped and guided by Olins foundational work and by our initial (and to me defining) conversations in the 1980 s and 1990s. This led to the introduction of MBA, MSc and BA (Hons) electives on corporate identity, corporate branding and corporate marketing at 
the Universities of Bradford (England), Brunel (London) and Strathclyde (Scotland). A number of my students have followed me in taking marketing doctorates in the broad corporate identity field. Wally Olins was one of my examiners for my PhD in corporate identity.

Shortly after taking my PhD in 1996 I was, in 1999, appointed Professor of Corporate Identity at Bradford University School of Management and in the same school was also appointed Professor of Corporate Brand/Identity Management. In 2007, Brunel University Business School (London) elected me to the Chair of Professor of Corporate Marketing.

All of the above rather surprised Olins - as it astonished me - but as I told him, it was largely his fault!

\section{WALLY OLINS: A HERALD OF THE ENGLISH CORPORATE MARKETING REVOLUTION?}

Without question, Olins was a central figure who helped lay the foundations of in what, today, I would call the English Corporate Marketing Revolution. Others include David Bernstein and Stephen King. Of these only David Bernstein-(the renowned communications authority) survives. I wish him ad multos annos.

Interestingly, and perhaps significantly, they were linked by their education and initial profession. All three were Oxford undergraduates. David Bernstein read English. Stephen King read The Greats (Greek, Latin, Classical History and Philosophy) and Wally Olins read history. Today's corporate marketing students will, perhaps, be surprised that none of them read marketing or management at Oxford. However, all of them - at one time or another held prominent positions in advertising.

\section{The mighty troika: Bernstein, King and Olins}

In their composite, the theses of Bernstein, King and Olins implicitly (rather than explicitly) presented cogent arguments why organisations and not only products should be the focus of marketing and the management of products and product brands.

\section{Stephen King}

Stephen King (1991) alerted us to the importance and the inexorable rise of serviceorientated company brands. His thesis on service-orientated company brands presaged the formal introduction of the corporate brand notion in 1995 and subsequent explications (see: Balmer, 1995, 1998, 2001, Ind, 1998).

\section{David Bernstein}

David Bernstein's (1984) treatise formally introduced the corporate communications notion. Unlike marketing communications, which was directed at customers and which focussed on products and product brands, corporate communications was directed at stakeholders and focused on organisations.

\section{Wally Olins}


Olins (1978) disquisition asserted that senior managers had a responsibility to understand and manage their organisation's corporate identity. It was insufficient and prospectively dangerous to only focus management attention solely on the identities of products/product brands.

Their collective insights meaningfully informed my formal introduction and explication of corporate marketing (Balmer, 1998) along with later refinements and iterations of this broad area.

Without realising it, all three were corporate marketing's godparents and the most important of these was, unquestionably, Wally Olins.

\section{FINAL REFLECTION; FINAL TRIBUTE}

With the death of Wally Olins we have come to the end of an era. Olins was sui generis - he was one of a kind. Wally Olins was a man of many parts, a man of many identities. He was an effective protagonist and consultant of both corporate identity and branding. He was a writer and a man of ideas. Wally Olins not only helped to shape the corporate identities and brands of numerous organisations but also helped to shape an industry. Importantly, his binary insights on corporate identity inspired and influenced the first wave of scholars working in the business identity and corporate marketing domains.

In bringing my personal tribute to a close I think it is fair to say that Wally Olins was not only one of a kind but was also, regrettably, the last of $a$ kind. Sadly, we shall not see his like again. He will be sorely missed.

\section{0}

\section{References}

Aldersey-Williams, H. (2000) Ten reasons why corporate identity is irrelevant. Royal Society of Arts Journal 4(4): 4-5.

Balmer, J.M.T. (1995) Corporate branding and connoisseurship. Journal of General Management 21(1): 24-46.Balmer, J.M.T. (1998) Corporate identity and advent of corporate marketing. Journal of Marketing Management 14(8): 963-996|

Balmer, J.M.T. (2001) The three virtues and seven deadly sins of corporate brand management. Journal of General Management 27(1): 1-17.

Balmer, J.M.T. (2002) Of identities lost and found. International Studies of Management and Organizations 32(3): 11-22.

Balmer, J.M.T. (2008) Identity based views of the corporation: Insights from corporate identity, organisational identity, social identity, visual identity, corporate brand identity and corporate image. European Journal of Marketing 42(9-10): 879-906.

Balmer, J.M.T. (2012) Corporate brand management imperatives: Custodianship, credibility, and calibration. California Management Review 54(3): 6-33

Balmer, J.M.T. and Greyser, S.A. (2002) Managing the multiple identities of the corporation. California Management Review 44(3): 72-86. 
Balmer, J.M.T., Stuart, H. and Greyser, S.A. (2009) Aligning identity and strategy: Corporate branding at British airways in the late 2oth century. California Management Review 51(3): 623.

Bernstein, D. (1984) Company Image and Reality. Eastbourne: Holt Rinehart and Winston. Cornelissen, J.P., Haslam, S.A. and Balmer, J.M.T. (2007) Social identity, organizational identity and corporate identity: Towards an integrated understanding of processes, patternings and products. British Journal of Management 18(1): 1-16.

He, H.-W. and Balmer, J.M.T. (2007) Identity studies: Multiple perspectives and implications for corporate-level marketing. European Journal of Marketing 41(7/8): 765-785

Ind, N. (1998) An integrated approach to corporate branding. Journal of Brand Management 6(5): $323-329$

King, S. (1991) Brand building in the 1990s. Journal of Marketing Management 7(1): 3-13.

Melewar, T.C., Saunders, J. and Balmer, J.M.T. (2000) The salience of Olins' visual identity structures in relation to UK companies operating in Malaysia. Corporate Reputation Review 3(3): 194-200.

Melewar, T.C., Saunders, J. and Balmer, J.M.T. (2001) Cause, effect and benefits of a standardised corporate visual identity system of UK companies operating in Malaysia. European Journal of Marketing 35(3-4): 414-427.

Olins, W. (1978) The Corporate Personality: An Inquiry Into the Nature of Corporate Identity. London: Design Council.

Olins, W. (1979) Corporate identity: The myth and the reality. Journal of the Royal Society of Arts 127: 209-218.

Olins, W. (1984) The Wolff Olins Guide to Corporate Identity. London: Ashgate Publishing. Olins, W. (1986) The New Guide to Identity: How to Create and Sustain Change Through Managing Identity. London: Design Council/Gower Publishing.

Olins, W. (1989) Corporate Identity: Making Business Strategy Visible Through Design. London: Thames and Hudson.

Olins, W. (1991) Corporate identity and the behavioural dimension. Design Management Journal 2(1): 42-45.

Olins, W. (1999) Trading Identities: Why Countries and Companies are Taking on Each Others' Roles. London: Foreign Policy Research Centre.

Olins, W. (2000) Why companies and countries are taking on each other's roles. Corporate Reputation Review 3(3): 254-265. | Olins, W. (2002) Branding the nation - the historical context. Journal of Brand Management 9(4):241-248

Olins, W. (2004) On Brand. London: Thames and Hudson.

Olins, W. (2008) The Brand Handbook. London: Thames and Hudson.

Olins, W. (2014) Brand New: The Shape of Brands to Come. London: Thames and Hudson. 
Olins, W. and Morgan, C.L. (eds.) (1996) International Corporate Identity. London: Trafalgar Square Publishing.

Olins, W. and Selame, E. (1999) Audit Corporate Identity. London: Financial Times/Prentice Hall.

Pérez, A. and Rodriguez del Bosque, I. (2014) Organizational and corporate identity revisited: Toward a comprehensive understanding of identity in business. Corporate Reputation

Review 17(1):3-27.

\begin{abstract}
About the author
Professor John M.T. Balmer took his PhD at Strathclyde University, Scotland in 1996 and within 3 years was elected Professor of Corporate Identity at Bradford University School of Management. He subsequently was conferred the title of Professor of Corporate Brand/Identity Management in the same university in recognition of his seminal scholarship on both territories. In a similar vein, in 2007, he was appointed Professor of Corporate Marketing at Brunel University, London. All three Professorial positions are understood to be the first appointments of their kind. Since the early 1990s, he has been a leading proponent of the strategic importance of corporate identity. He is credited with writing the first articles on corporate brands (1995) and corporate marketing (1998) and is known for his seminal works on these areas. In 2006 he co-developed the corporate brand heritage notion. He is the founder, chairman and conference organiser of the International Corporate Identity Group. He is known for his articles in these areas which have been published in leading journals such as the California Management Review, European Journal of Marketing, Journal of Marketing Management, Journal of General Management, Journal of Business Ethics, Journal of Business Research, British Journal of Management, Long Range Planning, etc. He is Chairman of the Board of Senior Consulting Editors for the Journal of Brand Management.
\end{abstract}

